\title{
比較的良好な地山での支保工の 役割に関する実験的研究
}

\author{
中田雅博 ${ }^{1} \cdot$ 三谷浩二 ${ }^{2} \cdot$ 中川浩二 $^{3}$ \\ ${ }^{1}$ 正会員 工修 日本道路公団 圾験研究所 トンネル研究室室長 (テ194-8508 東京都町田市忠生1-4-1) \\ ${ }^{2}$ 正会員 日本道路公団 試験研究所 トンネル研究室主任 (テ194-8508 東京都町田市忠生1-4-1) \\ ${ }^{3}$ 正会員 工博 山口大学教授 工学部社会建設工学科（广755-8611 山口県宇部市常盤台2557）
}

\begin{abstract}
高速道路トンネル建設時にトンネル側壁部の押出し量として計測される最終内空変位量の頻度分布 を調へると，ほとんどが $20 \mathrm{~mm}$ 以下と小さく，支保工の変状もほとんどない。これは支保工が変位抑制 効果を発揮した結果なのか, 地山の性状に依存した結果であるのかという課題と, 何を基準に支保工 を增減するかといら課題を提起している。そこで，一般的な地山の現場を中心として支保工量を穦極 的に削減し, 变位量や支保工応力の変化を試験施工により検討し, 支保工削減の可能性と支保工の役 割を明らかにすることを試みた。 その結果, 变位は主に地山条件により決まり, 支保工の役割は変位 量を制御することよりもむしろ，髣みの增大や岩塊の抜け落ちを防ぐことにあると強く推察された.
\end{abstract}

Key Words : NATM, effect of support, measurement, convergence, deformation, standard tunnel support patterns

\section{1. はじめに}

公共投資のあり方が議論され，政府として公共事 業费縮减の目標が示される中で, 縮减に向けた具体 的な行動が今後効率的に高速道路ネットワークを拡 大するための大きな前提条件となっている. 特に路 線延長に占める比率が増大傾向にあるトンネルは, その建設費縮減への取り組みが非常に重要な課題と なり，この課題の解決のためには新技術，新工法な どの技術開発だけでなく，従来の考え方や基準の見 直しなどへの取り組みが求められて来ている.

再検討すべき課題の一つとして, 従来から経験的 な知見として扱われてきた支保工選定の考え方があ る. 具体的には，一般的な地山における支保工の役 割を明らかにして、建設中あるいは建設後に必要な 安全性と耐久性を確保しつつトンネル支保工量を削 減することの可能性を探るとともに，従来の経験的 知見を統一・体系化することである. 特に“地山に 適合する支保工を選定する”というNA T Mの考え 方から見ても, 支保工の役割を確認することは重要 な意味を有していると考える.

トンネルにおける支保の役割に関して，例えば
“トンネルの挙動は周辺地山により決まり，支保工 の役割は緩みの抑制である”とする考え方がある一 方で、“支保工は地山のひずみ(変位量)をある程度 制御できる”とする認識もある. 本来, 支保工の効 果は地山条件によって異なると考えられる.しかし， 支保工が变位量にどの程度の影響を与えるかという 基本的な事項については曖昧なまま議論が進められ， 変位量や支保工の評価に関して現場で混乱が生じて いるものと考える．例えば現場ではひずみにより管 理基準值が設定されることも多い. 現場感覚として は地山が比較的良好で支保の剛性が天端沈下・内空 変位に及ぼす影響は小さいと思われても，変位によ る管理基準値が支保工変更の目標値として理解され 適用されている事例もあるように思われる.この原 因は，標準工法がNATMになり，従来の “緩み土 圧”の考え方が後退し，特性曲線で表現されるよう な応力とひずみの考え方で説明が試みられるように なったことや，いろいろな概念が整理されないまま 議論が進められてきたことにあるように考える．ま た，支保工の増減が変位量に与える影響について現 場において実証的に明確に確認されていないことも 原因の一つと考える. 合理的な支保工を選定するた めには，単に標準支保パターンを画一的に適用する 
のではなく，地山に合わせて支保工量を削減するこ とができることを確認し，支保の役割や支保工増堿 の基準を明確にすることが工费縮減と地山に適合す る支保工選定の観点から大きな意味を有するもので あると考えた．標準支保パターンとは，分類された 地山毎 $(\mathrm{B} \sim \mathrm{D}$ II $)$ に鋼アーチ支保工, 吹付けコン クリート，ロックボルトの組合わせにより設定され た支保工を言う。

これらのことから，筆者らは日本道路公団（以下 $\mathrm{J} \mathrm{H}$ )のトンネル建設において多くの割合を占める 比較的良好で一般的な地山（変位量が大きくなく， 一般的施工法で施工可能な地山）において，現地で の実施工の中で標準支保と削減支保を施工し, 比較 するという実験を行った。これらの点については協 カいただいたほとんどの現場での技術者から，少な くとも現地実験当初には大きな関心を寄せていただ いたことから，その実務的な必要性がうかがわれた。 本報告ではこの現地実験から得られた知見について 報告する。

\section{2. 支保エの役割に関する研究の現状と課題}

N A T Mは，在来の工法と比べて支保工材料が 異なるだけでなく，支保に作用する荷重や地山の挙 動は，応力とひずみの考え方によっていることや， 計測・観察を用いて地山状況に合う支保工を選定す ることに大きな特徵がある.この点についていくつ

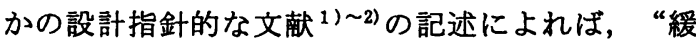
み荷重”の概念と“応力・ひずみ”による地山挙動 の概念が示されているが，その取り扱い区分が明確 に示されていない。

地山と支保工の関連に関する既往の研究につい ては, 主に以下の内容と考えられる.

(1)切羽観察結果, 計測值等から，支保パターン毎の 傾向を論じ，地山状㫛に対する支保工の妥当性に関 しての議論. 計測值相互の関係を論じ，支保工選定 の指標を明らかにする研究 ${ }^{3) ~ 11) . ~}$

(2)地山岩種ごとの変位の傾向を論じ, 地山毎での挙 動の違いから，岩種による特性を議論し，地山の挙 動を説明する地山物性值等の指標の研究 ${ }^{12)}$ 18).

(3)計測データを理論的に整理し，理論により地山の 挙動を把握しようとする研究19) 22).

(4)模型実験等により各支保工の効果を定性的，定量 的に評価しようとする研究23) 26).

これらの研究の目的は, 現場での計測結果, 切羽 観察記録, 支保工の変状, 地山物性值等の情報から

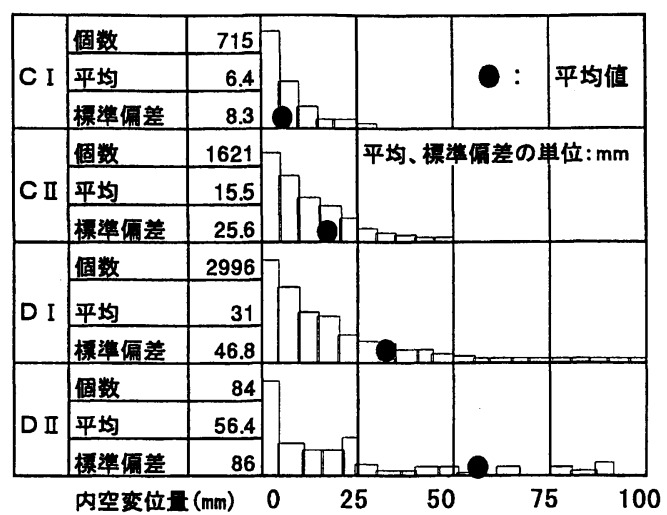

図-1 地山等級毎の内空変位量の頻度分布

地山や支保工の挙動と健全性を説明・評価し, 適正 な支保工を選定する指標や基準を見つけることにあ る. しかし一方で次に示す課題点も指摘することが できる.

(1)変位量の大きいトンネルや. 切羽の不安定なトン ネル等, 難渋したトンネルの研究は多くなされてい るが，一般的な地山での支保工のあり方に関しての 研究は少ない。

(2)支保工の役割を定性的にも定量的にも明確にする ことなく議論されている研究が多い.

(3)従って，適正な支保工の判断基準が明確でない.

つまり, 地山の安定性と適正な支保工の判断基 淮やクライテリアが明確でない，これに起因して適 正な支保工量の議論が，「支保工の増減により変位 量は変化する」との概念が定量的に確認がなされて いない，支保工自体のもつ変位量への抑制効果は小 さいとの指摘27)があるが，実際の計測結果を基に議 論されていない点を指摘することができる，また， 同様の地山に 3 種類の支保工を試験的に施工し, 緩 み領域の違いや支保工削減の妥当性を，変位量や支 保工応力, 変状の有無から議論 ${ }^{28)}$ がされているが, 非常に硬質な地山に対してであり，支保工の役割は 明確となっていない。

図-1は，平成 7 年までのすべての岩種を含む高速 道路トンネルでの施工時の計測データから， J Hの 地山区分による地山等級毎に最終内空変位量（以下 内空変位量)を頻度分布で示したものである.なお最 終内空変位量とは, 切羽進行に伴い一定值に収束し たトンネル両側側壁の押出し量（側壁間の縮小量） をいい，コンバージェンスメジャ一等で計測される 值の変化で示される．図-1は次のことを示してい る.

(1)地山が悪くなるに従い，内空変位量の平均値は大 
表-1 変位量の小さな断面の頻度

\begin{tabular}{|l|c|c|}
\hline & 内空変位 & 天端沈下 \\
\hline $20 \mathrm{~mm}$ 以下の比率 & $75 \%$ & $84 \%$ \\
\hline $30 \mathrm{~mm}$ 以下の比率 & $84 \%$ & $90 \%$ \\
\hline
\end{tabular}

きくなる．地山が悪くなると地山強度が小さくなり， それに応じて内空変位量が大きくなることを意味し ている.

(2)地山が悪く大きな支保工量を採用するような地山 においても，良好な地山と比較して標準偏差は大き くなるものの, 全体として内空変位量が小さい断面 が多く，頻度分布の形状もあまり異なっていない。

これらに関しては，「支保工の効果により変位量 が抑制された」と解釈するのか，「切羽観察の結果 地山は悪いと評価されたが，結果的に地山の性状に 支配され小さい值となった」と解釈するのかという 問題を提起している．また従来の研究の中でも明ら かにされていない問題である.

地山等級毎の内空変位量の頻度分布から, $20 \mathrm{~mm}$, $30 \mathrm{~mm}$ 以下の変位量の占める比率を示したのが表-1で ある.この表から比較的变位量の小さな一般的な領 域のデータが全体の8 9割を占め, 変形余裕量や変 位量を問題にする必要のない普通の地山が大部分を 占めていることがわかる.

\section{3. 現地実験}

\section{（1）現地実験の方法}

これまで現場検証された例がほとんどないことを 念頭に比較的良好な地山で, 支保工削減の変位量一 の影響と，支保工の役割を明らかにすることを目的 として現地実験を実施した．そこでは(1)支保工量を 削減することで，変位量や支保工応力值にどのよう な変化が生じるのか，(2)その場合の支保工の実トン ネルでの役割をどこまで説明できるのか，について 明らかにすることを試みた．実験の方法としては， 実トンネルにおいて图-2に示すような地質が同一と 想定される隣接する区間で，標準支保パターンと， ロックボルト本数やH鎆を削減した支保パターン, 一掘進長を伸ばしたパターン等を施工し，それぞれ の区閒の中閒を計測断面として変位量，支保工态力 を比較することとした，なお，基本的に変位量の計 測は, 計測断面の前後 $1 \mathrm{~m}$ でも実施した.

一連の現地実験の概要及び変位量・支保工応力の

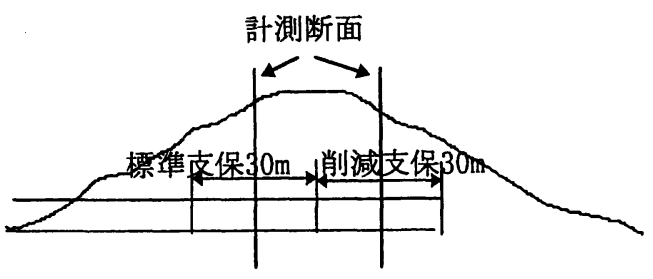

図-2＼cjkstart現地実験の方法の概念図

計測結果の一覧を表-2に示す，なお，支保工を増や した 2 例は，支保工量の多い変更後の支保パターン を標準支保とし，支保工量の少ない変更前支保パタ 一ンを削減支保として取り扱っている.また，上半 最大平均ロックボルト軸力とは，一本のボルト軸力 の最大値を上半部 (一般的には 3 本) で平均した值を いい, 下半部最大平均ロックボルト軸力とは，側壁 部の最大下半ボルト軸力を両側壁（各 1本）で平均 した值をいう．平均吹付けコンクリート応力は，上 半部分の 3 筒所（天端部、両有部）の発生応力の平 均值をいう。

現地実験は B 〜 D I クラスの広い範囲の地山等級 で実施している。しかし， B， C I クラスの地山で は，支保工の効果が小さいと想定されること，Dク ラスの地山では支保工の機能として比較的大きいと 考えられるH鋼を削減した実験例がないことから， ここでは現地実験結果の中から主としてC II 地山を 対象として検討するものとする.

\section{(2) 計測結果の傾向}

7 トンネルで地山物性試験として一軸圧縮試験を 実施し29個の試験結果を得ている．この一軸圧縮強 度から算定される地山強度比と内空変位量の関倸を 図一に示した.ここではコアから得られる一軸圧縮 強度を地山の一軸圧縮強度としている。

図-3は，地山強度比が大きくなると変位量はい くらか小さくなる傾向を示しており，筆者らが示し ている傾向 ${ }^{31)}$ と同様な結果となっている，なお，本 現地実験でのトンネルで支保工の変状は見られなか った.

\section{(3) 支保工削減の最終变位量への影蔀 a) 平均的評価}

標準支保と削減支保を実施したトンネルにおける， 各切羽での切羽評価点 ${ }^{32)}$, 内空変位量, 天端沈下量 の縦断方向変化を図化した 1 例（表-2に示す№. 11 のトンネル）を図-4に示した．縦断方向の測定間隔 


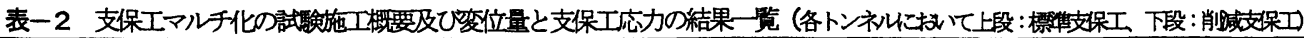

\begin{tabular}{|c|c|c|c|c|c|c|c|c|c|c|c|}
\hline No & $\begin{array}{l}\text { 地哲・ } \\
\text { 施工法 }\end{array}$ & $\begin{array}{l}\text { 地山等級 } \\
\text { 削減支保 }\end{array}$ & $\begin{array}{l}\text { 地 山 } \\
\text { 強度 } \\
\text { 比注) } \\
-3\end{array}$ & $\begin{array}{l}\text { 変 } \\
\text { 価 } \\
\text { 点 }\end{array}$ & $\begin{array}{l}\text { 初期天端 } \\
\text { 沈下速度 } \\
(\mathrm{mm} / \text { 日) }\end{array}$ & $\begin{array}{l}\text { 天端沈下 } \\
\text { 量 } \\
\text { (mm) }\end{array}$ & $\begin{array}{l}\text { 初期内空 } \\
\text { 変位速度 } \\
\text { ( } \mathrm{mm} / \\
\text { 目) }\end{array}$ & $\begin{array}{l}\text { 内空変 } \\
\text { 位量 } \\
(\mathrm{mm})\end{array}$ & $\begin{array}{c}\text { 上半最大平 } \\
\text { 均 } \mathrm{RB} \text { 軸力 } \\
(\mathrm{kN})\end{array}$ & $\begin{array}{c}\text { 下半最大平 } \\
\text { 均 } \mathrm{RB} \text { 軸力 } \\
(\mathrm{kN})\end{array}$ & $\begin{array}{c}\text { 平物SC応力 } \\
\left(\mathrm{N} / \mathrm{m}^{2}\right)\end{array}$ \\
\hline \multirow[t]{2}{*}{1} & \multirow{2}{*}{$\begin{array}{l}\text { 碳 } \\
\text { ショール゙チチ }\end{array}$} & \multirow{2}{*}{\begin{tabular}{|l}
$\mathrm{B}$ \\
下半ボルト
\end{tabular}} & 92 & 85 & 1 & 3 & 12 & 23 & 23.5 & - & 0.34 \\
\hline & & & 54 & 81 & 1 & 6 & 0.5 & 81 & 33.3 & - & 0.75 \\
\hline \multirow[t]{2}{*}{2} & \multirow{2}{*}{$\begin{array}{l}\text { 碳 } \\
\text { 補助ざチ全断面 }\end{array}$} & \multirow{2}{*}{\begin{tabular}{|l|} 
B \\
12 本 $\rightarrow 8$ 本 \\
\end{tabular}} & 33.6 & 76 & 0.6 & 1.1 & 0.9 & 15 & 6. 9 & - & - \\
\hline & & & 30.3 & 72 & 0.5 & 15 & 0.3 & 1 & 13. 7 & - & - \\
\hline \multirow[t]{2}{*}{3} & \multirow{2}{*}{$\begin{array}{l}\text { 础岩·頁岩 } \\
\text { 補助心全断面 }\end{array}$} & \multirow{2}{*}{$\begin{array}{l}\text { CI } \\
\text { 下半ボルト }\end{array}$} & 149 & 71 & - & 14 & - & 0.6 & 11.7 & 0.98 & -0.18 \\
\hline & & & 141 & 68 & 0.4 & 6 & -1 & -2 & 12.7 & - & -0.33 \\
\hline \multirow[t]{2}{*}{4} & \multirow{2}{*}{ 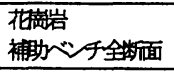 } & \multirow{2}{*}{$\begin{array}{l}\mathrm{CI} \\
\text { 下半ボルト }\end{array}$} & 45 & 78 & 18 & 25 & 28 & 44 & 17.6 & 10.8 & 0.022 \\
\hline & & & 14 & 63 & 6.1 & 6.4 & 116 & 124 & 25.5 & 22.5 & 0.07 \\
\hline \multirow[t]{2}{*}{5} & \multirow{2}{*}{$\begin{array}{l}\text { 頁岩 } \\
\text { 補助心゙ンチ全断面 }\end{array}$} & \multirow{2}{*}{$\begin{array}{l}\text { CII } \\
\text { H艥L }\end{array}$} & - & 48 & 3 & 4 & 49 & 5.8 & 11.7 & 53.9 & 0.04 \\
\hline & & & $=$ & 54 & 1 & 3 & 41 & 48 & 7. 2 & 37.2 & 2. 41 \\
\hline 6 & 頁岩·础岩 & CII & - & 59 & 4 & 5 & 0.6 & 13 & - & - & - \\
\hline & ショール゙チ & H鋼無L & - & 63 & 1 & 3 & 0.6 & 3.1 & - & $=$ & - \\
\hline 7 & 黙色崱岩 & CII & - & 61 & 0.6 & 24 & 0.4 & 17 & - & - & - \\
\hline & 補助んチ全断面 & 珠婮無L & - & 65 & 0.9 & 7.9 & 0.9 & 85 & - & - & - \\
\hline 8 & 砂页頁岩 & CII & 19.3 & 52 & -1 & 0.7 & 81 & 118 & 22.5 & 83.3 & 1. 49 \\
\hline & 補助べ全断面 & H釷無L & 148 & 52 & 16 & 23 & 4.1 & 102 & 41.1 & 64.7 & 3. 12 \\
\hline 9 & 础窝頁岩 & CII & 19.3 & 52 & -1 & 0.7 & 81 & 118 & 22. 5 & 83.3 & 1. 49 \\
\hline & 補助んチ全断面 & 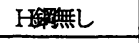 & 149 & 33 & 29 & 9.6 & 16.7 & 33.4 & 132 & 134 & 6.4 \\
\hline 10 & 流效岩兵 $\mathrm{T} \mathrm{f}$ & CII & 7.3 & 78 & -0.1 & -17 & 19 & 28 & 20.6 & 19. 6 & 0.09 \\
\hline & ショーM゙ル & H釷墲L & 17.1 & 67 & 3.0 & 0.7 & 27 & 3.4 & 21.6 & - & 1.95 \\
\hline 11 & 頁岩 & CII & - & 60 & 21 & 49 & 3.8 & 9 & 51.9 & 92.1 & 1. 99 \\
\hline & 補助以“全断面 & 下半ボルト & 7.5 & 63 & 0.7 & 15 & 0.5 & 16 & 14.7 & $=$ & 1.36 \\
\hline 12 & 頁岩 & & 5.1 & 48 & 3 & 7 & 22 & 27 & 20.6 & 6.37 & 0.82 \\
\hline & ショードンチ & 下半ボレト & 247 & 56 & 3 & 5 & 11 & 2 & 22.5 & - & 0.56 \\
\hline 13 & 砂岩・顗岩 & CII & 138 & 52 & 6 & 14 & 3.8 & 9.1 & 11.8 & - & 1.04 \\
\hline & 補助心于全断面 & 下半ボルト & 221 & 56 & 6 & 17 & 35 & 13.8 & 21.6 & - & 4.1 \\
\hline 14 & 石英安山荘 & CII & - & 63 & 3 & 14 & 22 & 16.4 & 4. 3 & 12.7 & 5.58 \\
\hline & & $12 \rightarrow 135 \mathrm{~m}$ & - & 67 & 3 & 11 & 2 & 13.4 & 4.4 & 1.57 & 1.45 \\
\hline 15 & 頁岩・础岩 & & - & 74 & 32 & 5.6 & 47 & 84 & 2.6 & 48.0 & - \\
\hline & 補助べチ全断面 & 15 本 $\rightarrow 11$ 本 & - & 67 & 7.3 & 112 & 12 & 22 & 5. 1 & 17.6 & - \\
\hline 16 & 同上 & CII & - & 74 & 32 & 5.6 & 47 & 84 & 2. 6 & 48.0 & - \\
\hline & & $12 \rightarrow 15 \mathrm{~m}$ & - & 59 & 7.6 & 15.6 & 6.6 & 17.9 & 16.7 & 13.7 & 0.31 \\
\hline 17 & 同上 & & - & 67 & 29 & 42 & 5 & 6.7 & - & - & 0.43 \\
\hline & & 15 本 $\rightarrow 11$ 本 & - & 63 & 24 & 3.4 & 27 & 5.6 & - & - & 1.98 \\
\hline 18 & 硠·頁岩 & CII & 45 & 69 & -1 & 21 & 19 & 83 & 46.6 & 48.0 & 1. 89 \\
\hline & 補助い゙チ全断面 & 15 本 $\rightarrow 11$ 本 & 39.6 & 61 & 16 & 41 & 11 & 3.9 & 29.4 & 9. 31 & 0.43 \\
\hline 19 & 流效岩質 $\mathrm{T}$ f b & CII & 14.4 & 65 & 3.7 & 7.6 & 0.1 & 23 & 45.1 & 66.6 & 0.36 \\
\hline & 補助べンチ全断面 & 15 本 $\rightarrow 11$ 本 & 19.7 & 63 & 0.3 & 24 & 11 & 24 & 32.3 & 19. 6 & \begin{tabular}{|l|}
-0.07 \\
\end{tabular} \\
\hline 20 & 花端岩 & & 228 & 63 & 2 & 4 & 44 & 6.1 & 18. 6 & 25.5 & 0.9 \\
\hline & 補助べチ全偭 & $1.2 \rightarrow 1.5 \mathrm{~m}$ & 482 & 67 & 3 & 5 & 3.6 & 7.1 & 13.7 & 16.7 & 0.09 \\
\hline 21 & 買岩 & CII & - & 52 & 38 & 215 & 10.8 & 37 & - & - & - \\
\hline & ショール゙チ & 16-29本增 & - & 48 & 32 & 16.1 & 5.1 & 317 & - & - & - \\
\hline 22 & 粘板岩 & CII & 37.3 & 67 & 3 & 6 & 23 & 46 & 13.7 & 33.3 & 1. 31 \\
\hline & ショール & $12 \rightarrow 1.5 \mathrm{~m}$ & 29 & 67 & 2 & 4 & 29 & 3.9 & 6.76 & 13.7 & 0.67 \\
\hline 23 & 凝灭岩 & $\mathrm{CII}$ & - & 63 & 4.9 & 122 & 43 & 185 & 51.9 & 48.0 & - \\
\hline & ショール゙チ & 注 -2 & - & 67 & 31 & 113 & 32 & 14.9 & 33.3 & 35.3 & - \\
\hline 24 & 頁岩·础岩 & $\mathrm{DI}$ & - & 56 & 0.9 & 26 & 22 & 5.1 & 15. 7 & 23.5 & 2.92 \\
\hline & 補助びチ全断面 & $4 \mathrm{~m} \rightarrow 3 \mathrm{~m}$ & - & 48 & 0.8 & 25 & 21 & 4 & 27.4 & 22.5 & 4.94 \\
\hline 25 & 同上 & $\mathrm{DI}$ & - & 56 & 0.9 & 26 & 22 & 5.1 & 15.7 & 23.5 & 2. 92 \\
\hline & & 18本 $\rightarrow 15$ 本 & - & 41 & 0.7 & 64 & 05 & 24 & 33.3 & 13.7 & 2. 06 \\
\hline 26 & 泥岩 & D I & 155 & 56 & 0.9 & 8.5 & 19 & 129 & 20.6 & 31.4 & 1. 6 \\
\hline & ショールの & $4 \mathrm{~m} \rightarrow 3 \mathrm{~m}$ & 0.77 & 59 & 4 & 16.4 & 6 & 39.2 & 106 & 140 & 2.41 \\
\hline 27 & 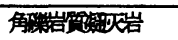 & CII & 114 & 56 & 28 & 7.9 & 41 & 9.7 & 18.6 & 10.3 & 0.07 \\
\hline & 補助へ千全断面 & 14本 $\rightarrow 11$ 本 & 80 & 48 & 42 & 86 & 53 & 10.8 & 42.1 & 16.7 & 0.86 \\
\hline 28 & 泥岩 & $\mathrm{CI}$ & 26 & 67 & 32 & 66 & 0.9 & 5.3 & 12.6 & 22.3 & -0.1 \\
\hline & 補助べ全糆 & 下半ボ゙レト & 13.7 & 62 & 44 & 14.1 & 3.5 & 17 & 1. 67 & - & -0.1 \\
\hline
\end{tabular}

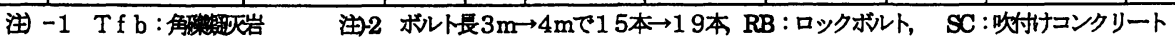

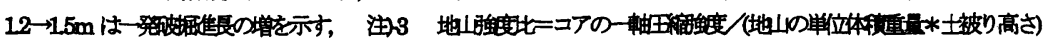




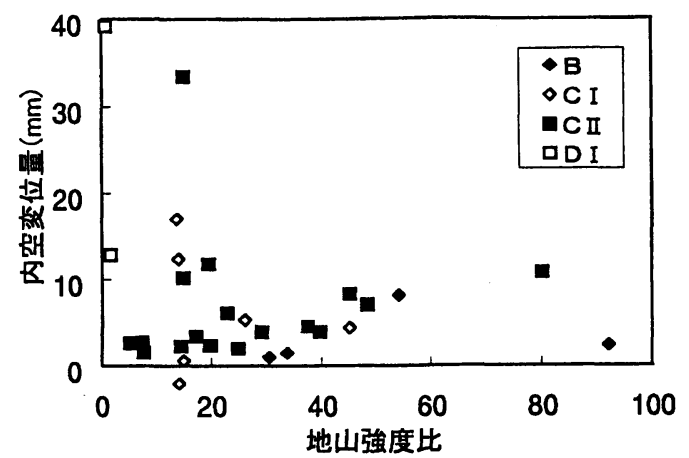

図-3 試験施工区間の地山強度比と内空変位量

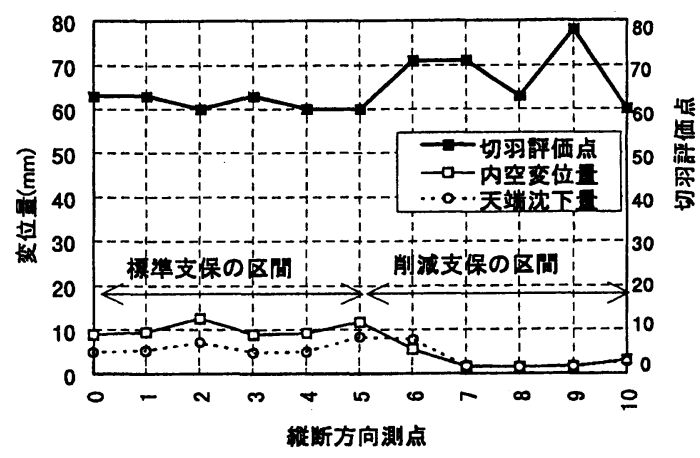

図-4 繸断方向の切羽評価点と変位量(トンネル No.11)

は6mであるので，標淮区閒と削減区間を加えた全体 延長は60m程度である. 切羽評価点とは，J Hの旧 切羽観察様式を用い, 切羽の直接観察により 9 の項 目に関して 4 つのカテゴリーで評価した結果を，0 〜100点となるように点数化した数値をいう.この 值は地山の良否を相対的に表現し，0点が最も悪い 地山で，100点が最良の地山を示している．図-4に 見られるようにトンネル深部においても場所によっ て切羽評価点は変動する，従って標準支保区間と削 減支保区間の比較において地山条件も考虑した取り 扱いが必要と考えた.

図-5，6に表-2に示した全トンネルの標準支保区 間での切羽評価点と天端沈下量, 内空変位量との関 係を示す. 図-5, 6から天端沈下量, 内空変位量は B， C I ， C II の順に評価点の低下とともに分布の ばらつきが大きくなる傾向がうかがえる。このこと から評価点と変位量から見るかぎり，B，CIに比 べて C II は広い範囲の地山を含んでいることがわか る. また，地山区分が B， C I クラスは，切羽評価 で評価区分してもそれぞれのグループにまとまる傾

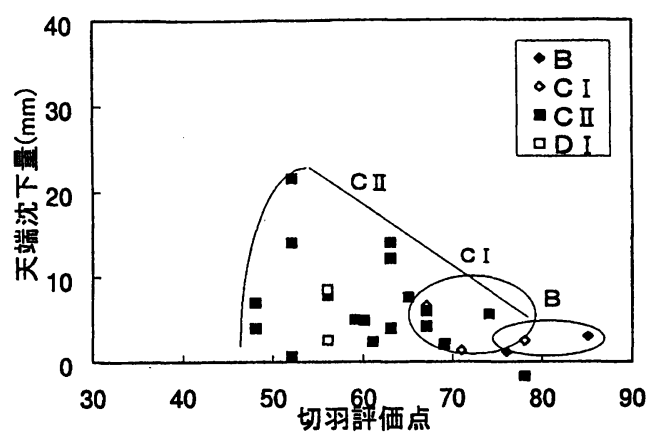

図-5 標準支保区閒の切羽評価点と天端沈下量

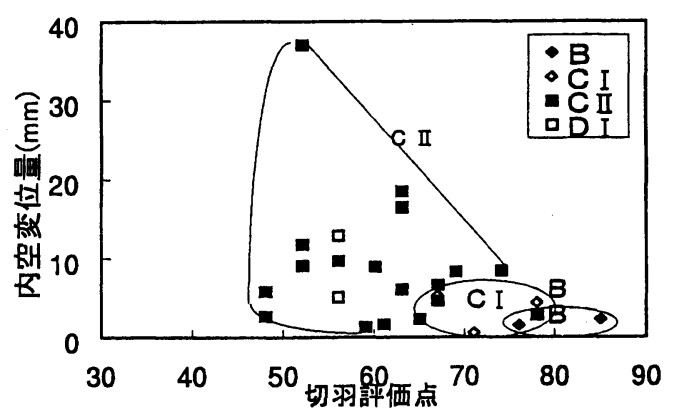

図-6 標準支保区閒の切羽評価点と内空変位量

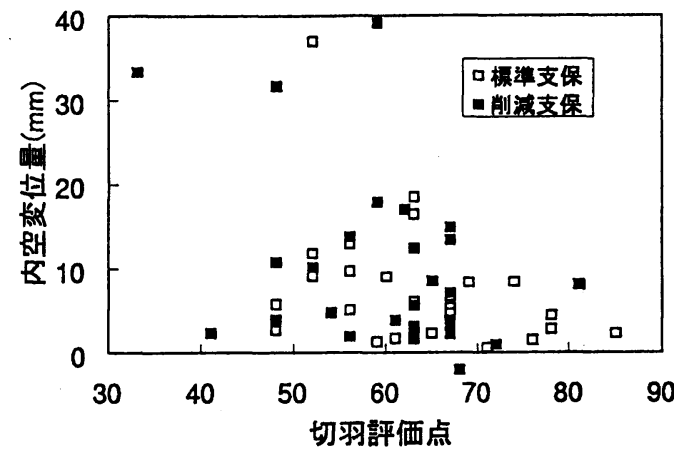

図-7 支保の削減前後の内空変位量の分布

向にあるが， C II， D I クラスでは両分布範囲が混 在しており，分離が困難である。

図一7は図-6に削減支保区閒のデータを加え，標準 支保区閒と削減支保区間の内空変位量の比較という 視点で表したものである．図より標準支保区間と削 減支保区閒それぞれの分布に明確な差は見られない。 全データから C II 地山を抽出し，支保の削減に伴 う全データの平均変位量の変化と支保工削減ケース 毎に平均変位量の変化を示したのが表-3である.な お，支保削減ケースは大きく分けて次の 3 ケースで ある。 
表-3 切羽評価点と変位量の平均值

\begin{tabular}{|c|c|c|c|c|}
\hline \multicolumn{2}{|c|}{ 削減項目 } & \multirow{2}{*}{$\begin{array}{l}\text { 平均切 } \\
\text { 羽評価 } \\
\text { 点 } \\
61.4\end{array}$} & \multirow{2}{*}{$\begin{array}{l}\text { 平均内 } \\
\text { 空変位 } \\
\text { 量 } \\
8.6 \mathrm{~mm}\end{array}$} & \multirow{2}{*}{$\begin{array}{l}\text { 平均天 } \\
\text { 端沈下 } \\
\text { 量 } \\
6.0 \mathrm{~mm}\end{array}$} \\
\hline 全体 & 標淮支保 & & & \\
\hline & 削減支保 & 59.9 & $10.1 \mathrm{~mm}$ & $7.4 \mathrm{~mm}$ \\
\hline \multirow{2}{*}{$\begin{array}{l}\mathrm{R} B \text { 削 } \\
\text { 減 }\end{array}$} & 標準支保 & 61.1 & $10.3 \mathrm{~mm}$ & $8.1 \mathrm{~mm}$ \\
\hline & 削減支保 & 60.4 & $9.6 \mathrm{~mm}$ & $8.7 \mathrm{~mm}$ \\
\hline \multirow{2}{*}{$\begin{array}{l}\text { 一掘 進 } \\
\text { 長延鹿 }\end{array}$} & 標淮掘進長 & 66.8 & $8.9 \mathrm{~mm}$ & $7.4 \mathrm{~mm}$ \\
\hline & 把進長延長 & 65 & $10.6 \mathrm{~mm}$ & 8. $9 \mathrm{~mm}$ \\
\hline \multirow{2}{*}{$\begin{array}{l}\mathrm{H} \text { 鋼 削 } \\
\text { 減 }\end{array}$} & 標準支保 & 58.3 & $5.9 \mathrm{~mm}$ & $1.8 \mathrm{~mm}$ \\
\hline & 削減支保 & 55.6 & $10.5 \mathrm{~mm}$ & $4.4 \mathrm{~mm}$ \\
\hline \multirow{2}{*}{$\begin{array}{l}H \text { 鎆 削 } \\
\text { 減注-1) }\end{array}$} & 標準支保 & 59.6 & 4. $7 \mathrm{~mm}$ & $2.1 \mathrm{~mm}$ \\
\hline & 削減支保 & 60.2 & 6. $0 \mathrm{~mm}$ & 3. $4 \mathrm{~mm}$ \\
\hline
\end{tabular}

注-1）No. 9 のデータを除いた平均值

(1)標準支保から下半のロックボルト削減，もしくは ロックボルトのピッチを広くし全体的に本数を削減 したケース。

(2)一掘進長を伸ばしたケース。

(3)標準支保から $\mathrm{H}$ 鋼を削減したケース.

表-3から，以下のことがわかる.

(1)平均内空変位量, 平均天端沈下量とも変位量は

$1.5 \mathrm{~mm}$ 程度削減支保区間の方が大きい。

(2)標準支保区閒の地山と削減支保区間の地山とは, 削減支保区間の地山がわずかに悪い傾向にあるが， ほぼ同様の地山であるといえる.

(3)ロックボルトの削減ケースでは，標準支保区閒の 地山より削減支保区閒の地山の方が，地山はわずか 覀い傾向にある，平均天端沈下量は削減支保区間で 若干変位量が増加し, 平均内空変位量は僅かに逆傾 向を示しているが，全体的に大きな変化はない。

(4)一掘進長を伸ばしたケースの切羽評価点は, 他の ケースの切羽評価点より若干高い，標準掘進長の地 山に比べて掘進長を延ばした地山では，地山が僅か に悪くなる傾向にあり，両変位量は地山の変化に従 う傾向にあるが，その変化はわずかである.

(5)H鋼削減のケースでは, 標準支保区閒の地山より 削減支保区閒の地山の方が悪くなる傾向にあり，平 均内空変位量で約 $5 \mathrm{~mm}$, 平均天端沈下量で約 $3 \mathrm{~mm}$ 程度 変位が大きくなっている，これは，表-2に示す No. 9 (評価点が19点低下)のトンネルの変位量の変化 に影転されている.このトンネルを除いたデータの 平均值を同様に表-3の最下段に示す．これによると 削減支保区間で $1 \mathrm{~mm}$ 程度変位量が大きくなっている.

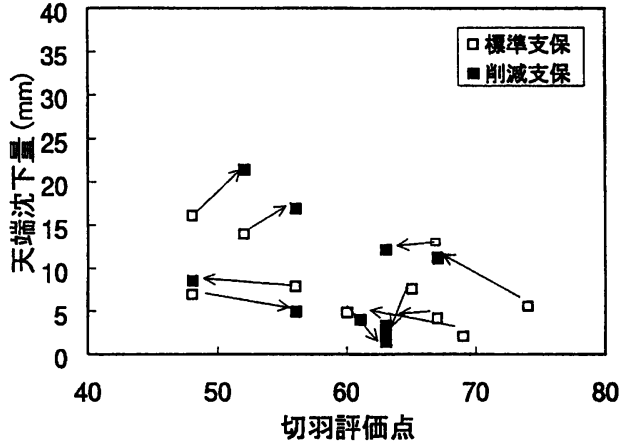

図-8 RB削減時の天端沈下量の変化

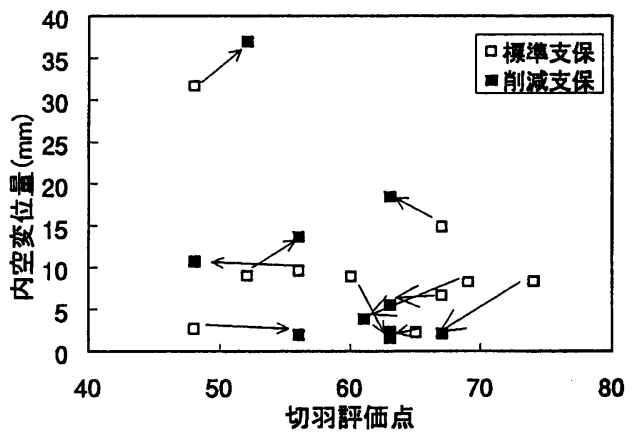

図-9 R B 削減時の内空变位量の変化

66平均変位量から見ると，いずれの場合も支保工削 減による変位量への影響が大きいとする傾向は見ら れない。

b) 個々の支保工削減が変位量に与える影霓

支保工の削減が，実用的なレベルで変位量にど の程度影響を与えているかについて詳細に検討する。

一般的に同一の地山に対して支保工を削減すれ

ば，変位量は増加の方向に向かい，また同一の支保 工に対して変位量は地山の良否に従った方向に向か うと考えられる.すなわち地山の良否は地山の評価 点で表され，支保工が同一の場合には地山評価点が 増加すると変位量は減少し，評価点が減少すると変 位量は増加すると考える。 この考え方により，C II 地山で実施した支保削減において, 標準支保区間と 削減支保区閒で地山の変化と変位量の変化を個々の 例について比較した.

イ)ロックボルトを一部削減したケース

ロックボルトを削減したケースに関して，内空変 位量と天端沈下量の変化を図-8と図-9に示す.

図中の矢印は同一の現場において，標準支保区間 から削減支保区間への切羽評価点と変位量の変化の 方向を示す. 図-8，9から以下のことがわかる. 


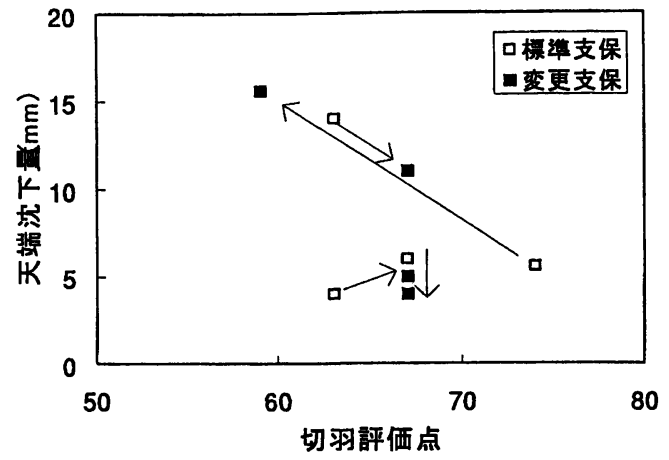

図-10一掘進長延長時の天端沈下量の変化

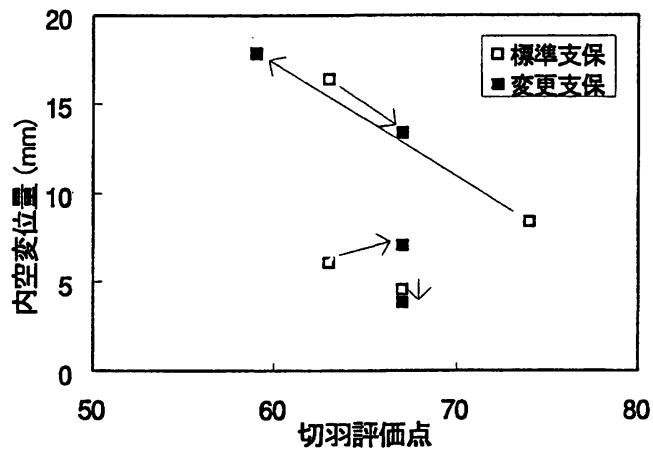

図-11 一掘進長延長時の内空変位量の変化

(1)切羽評価点と変位量の分布は, 切羽評価点の変化 に伴い変位量が增減する傾向にあり, 変位量はロッ クボルトの削減の有無にかかわらず地山評価点と相 関の傾向がうかがえる.

(2)天端沈下量・内空変位量のいずれの場合も，標準 支保区閒と削減支保区間のそれぞれのグループの分 布範囲に大きな相違が見られない。

(3)ロックボルト削減の天端沈下量への影製は, 地山 が悪くなったにもかかわらず変位量が小さくなる例 やほとんど沈下量が変化しない例が 5 例と多い。こ のことからしてもボルトの削減が、天端沈下量に影 響を及ぼしている傾向は見られない。

(4)ロックボルト削減の内空変位量への影響は, 天端 沈下量と同様に 10 例の内 5 例は地山が悪くなって も内空変位量が小さくなる例とほとんど変化しない 例である.このことからも, 同様にボルトの削減は 内空変位量へ有意な変化を与えていないと考える。

ロ）一掘進長を伸ばしたケース

事例は 4 例と少ないが，一掘進長を伸ばすことで 支保工の分担する範囲が広くなることによる相対的 な支保工の削減の影響が考えられる.

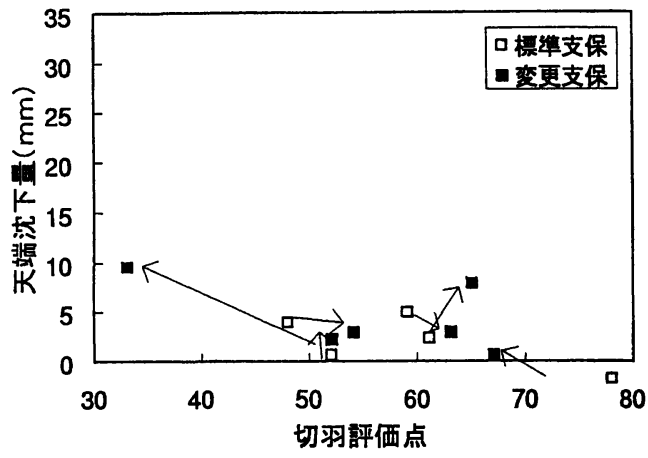

图-12 H鋼削減時の天端沈下量の変化

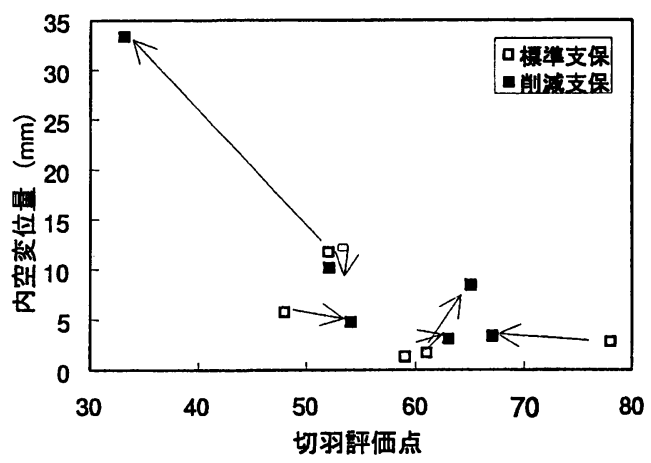

図-13 H鋼削減時の内空変位量の変化

図-10，11に一掘進長を伸ばしたケースの天端沈 下量と内空変位量の変化を示す.これらの図より次 のことが分かる.

(1)切羽評価点で15点地山が悪くなると天端沈下， 内空変位量ともに10mm程度大きくなった例はあるが, その他の例では変位量の変化は $1 \sim 3 \mathrm{~mm}$ 程度である. この傾向は，天端沈下量，内空変位量ともに同様 である。

(2)地山が覀くなっても，変位量が小さくなる例はな いが，変位量への影響が大きいとは考えられない。 八） H鋼を削隇したケース

H鋼を削減したケースに関して，切羽評価点の変 化に対応した天端沈下量と内空変位量の変化を図12と图-13に示す.

図-12，13から，次のことがわかる．

(1)H鋼を削減することによる天端沈下への影響は， 地山が悪くなり変位量が9mm程度増加したと思われ るのが 1 例, 地山は変化しないが6mm変位量が増加 した 1 例，変位量がわずかに増加した 2 例，変位量 が減少した 2 例となっているが，必ずしも変位量が 増加する結果となっておらず，变位量一の影翼は小 


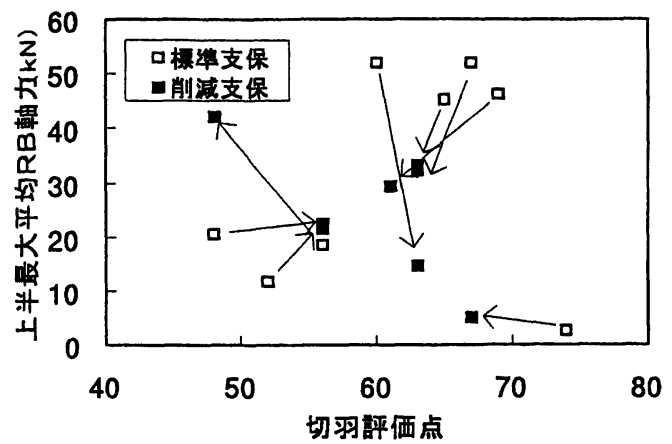

图-14RB削減時の上半最大RB軸力の芠化

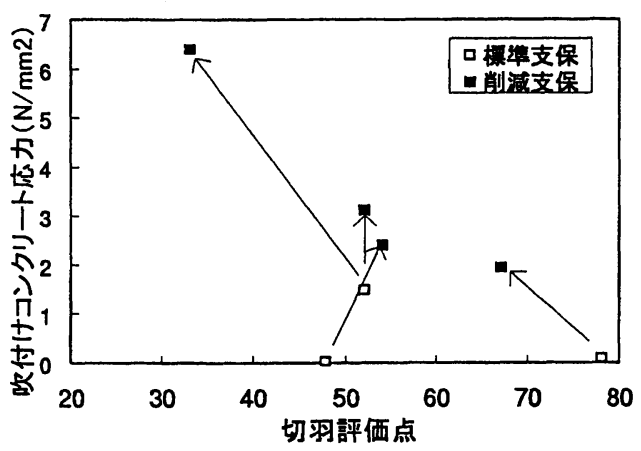

図-15 H鋼削減時の吹付けコンクリート応力の変化

さいと考えられる.

(2)内空変位量への影響としては 6 例中，変位量がほ とんど変化しない例と減少する例が 4 例あり， 1 例 は地山が変化したことにより変位量が大きく生じた と思われる例である。

(3)H䤡はロックボルトや吹付けコンクリートと比べ て，初期段階から機能する支保エであり，この削減 は初期の段階の緩みや崩落岩塊の移動を助長する照 念があるが，慎重に計測した場合においても顕著な 変位量の増加となっていない。

）支保工削減が変位量に及ぼす影䇾のまとめ

支保工削減が変位量に及ぼす影警のまとめとして 以下を得た。

(1)ロックボルト削減，一掘進長延長，H鋼削減は変 位量に有意な影響を与えていない。

(2)試験施工として慎重に計測と観察を実施し，分析 を行ったとしても，支保工削減の変位量への影響を 定量的に示すことは難しい.
（4）支保工削減の支保工応カへの影響

a ）ロックボルト削減による残存ロックボルト軸カ の变化

ロックボルトを一部削減した場合の残りのロック ボルト平均軸力と, 削減しない場合の上半最大平均 ロックボルト軸力との比較を行った結果を図-14に 示す. 図-14から以下のことが考察される.

(1)ロックボルト軸力の変化に関して, 切羽評価点と 軸力との相関関係は見られない.すなわち切羽評価 点の増加により, 残存ロックボルト軸力が減少する 傾向はみられない.

(2)評価点と軸力の変化の方向は様々な方向に変化し, 切羽評価点が変化しないか，もしくは悪い方に変 化しても軸力は減少しているケースが 8 例中 4 例 あり，ロックボルト削減により，他のロックボル トの軸力が増加する傾向はうかがえない.

(3)ロックボルト軸力の発現は, 地山の弾性変形だ けでなく不連続面の動きに関連しているとすると，

不連続面の走向・傾斜等とボルトの位置関係に影 響を受け，個々のロックボルト軸力は規則性のな い結果となったと考えられる.

\section{b) H 鋼削減の吹付けコンクリート応カへの影霎}

H鎆を削減することで，吹付けコンクリート态 カへの負担増加が考えられる．H鋼削減における 標準支保区間と削減支保区間のそれぞれの吹付けコ ンクリート応力を図-15に示す．吹付けコンクリー 卜応力測定の事例は少ないが, 図-15から次のこと が考察される.

(1)切羽評価点と吹付けコンクリート応力の分布は, 切羽評価点の变化に伴い吹付けコンクリート応カが 增减する傾向を示し, 応力と切羽評価点とに相関の 傾向がうかがえる.

(2)標準支保と削減支保の場合の吹付けコンクリート 応力の分布は、それぞれ異なる分布領域を示し， $\mathrm{H}$ 鋼の削減により吹付けコンクリート応カへの負担増 加の傾向がうかがえる.

(3)応力の負担増加は, $2 \mathrm{~N} / \mathrm{mm}^{2}$ 程度である.

\section{（5）支保工の役割}

支保工削減による変位量への影響は大きくない ことが実験結果からわかった. 変位を抑える効果が 大きくないとすると支保工の役目や増诚の基準を何 に求めるのかに関して述べ.

前述の現地実験において実施された地山岩石の 一軸圧縮試験の応力ーひずみ曲線から，一軸圧縮強 度を示す時の軸ひずみと一軸圧縮強度との関係を図 
-16に示した. 図一16より一軸圧縮強度を示す時の軸 ひずみの值は，0.25\%以上であり，地山の一軸圧縮 強度が低くなるほど, 相当するひずみは大きくなる 傾向にあることが認められる.ここで得られたひず みから，これに相当する計測内空変位量を式 (1) により得る.なお，天端沈下は土被りが大きくなる と側圧係数が 1 に近くなり, トンネル側方と同じ程 度の変位量になると想定されるので, 内空変位量で 変位量を代表する。

$$
\begin{gathered}
\delta=\mathrm{R} * \varepsilon / 100 *(1-\mathrm{a} / 100) * 2 \\
\text { ここで } \delta: \text { 計測される内空変位量 }(\mathrm{mm}) \\
\mathrm{R}: \text { 凮削半径 }(\mathrm{mm}) \\
\varepsilon: \text { ひずみ } \\
\mathrm{a}: \text { 先行変位率 }(\%)
\end{gathered}
$$

式(1) $て \mathrm{R}=6000 \mathrm{~mm}, \varepsilon=0.25 \%, a=40 \% ， と す る と ，$ 計測される内空変位量は $18 \mathrm{~mm}$ となる. 従って, 少な くとも $20 \mathrm{~mm}$ 程度の計測変位量では, 地山は一軸圧縮 強さ以下のレベルで挙動していると想定される.こ のことは, 不連続面の部分の安定性を除いて, $20 \mathrm{~mm}$ 程度の内空変位量の地山の安定性は悪いと判断され る状態にはないことを意味している.

また $20 \mathrm{~mm}$ 程度の小さな变位量の断面での支保工の 変状状況を調へててる. 代表的な支保エパターンC II, D I の地山において, 最終内空変位量が $20 \mathrm{~mm}$ 下, およびロックボルトの頭部プレートの変状や吹 付けコンクリートの亀裂等の変状の有る場合の頻度 を図-17に示した。岩種はすべての岩石種別の合計 と代表的な岩種, 花崗岩, 粘板岩, 泥岩・頁岩につ いて個々に示した。 图-17から, 内空変位 $20 \mathrm{~mm}$ 以下 では変状はほとんど生じていないことがわかる。な お， D I 地山でも C II 地山と全く同様の傾向がみら れている.

これらのことを整理すると, 変位量の小さい地山 では地山は一軸圧縮強度を示すひずみ以前の状態で 挙動し，支保工にも変状は見られない。また前述し た支保工自体にも大きな変位抑制効果があるとする 傾向が見られないことから考えると, 支保工の役割 は土圧に対抗する役目であるとは考えられない.

従来から支保工の役目として言われている, 岩塊 の抜け落ちを防ぎ地山のアーチ形状を保持し, 地山 の緩みを抑制する “緩み” の概念が，NATMにお いてもその役割として考えられる. 従って, 切羽の 評価や支保工の増減の目安に関しても繓みや岩塊の 抜け落ちを対象とした評価が必要になるものと考え る.
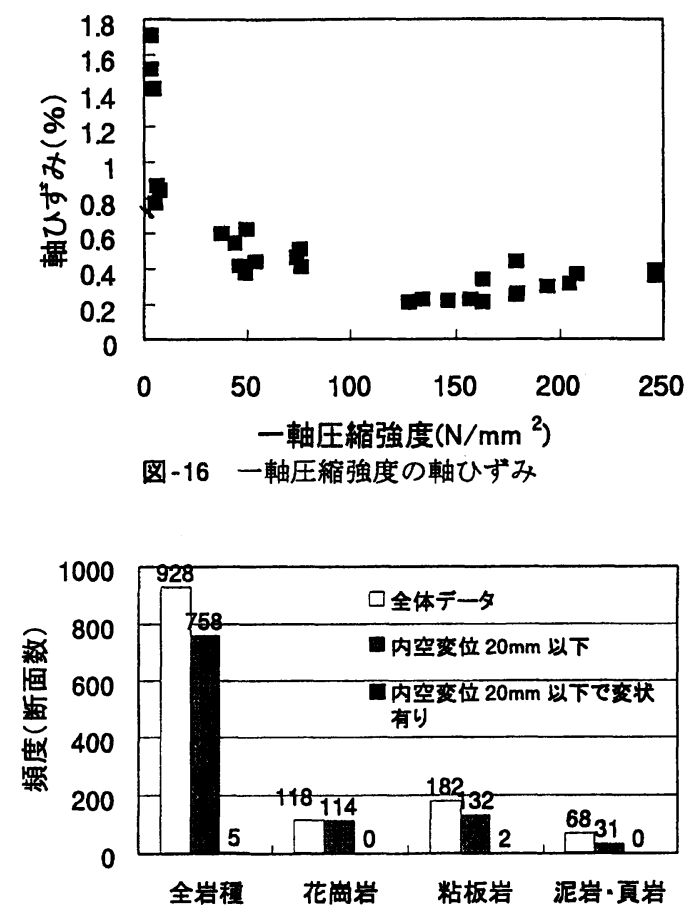

图-17 内空変位 $20 \mathrm{~mm}$ 以下の頻度と変状の颊度 (地山等級 C II)

\section{(6)まとめ}

今回の試験施工の計測結果の分析から, 支保工の 削減が変位量や応力值に与える影響について考察し， 明らかとなったことを以下にまとめる.なお今回の 試験施工の範囲ではH鋼やロックボルトを削減した 支保工においても，地山は安定しており，支保工の 変状や崩落なども発生することなく施工が可能であ った.

(1)C IIクラスの地山では，掘削により生じる変位量 は，主体的に地山によって決まるものと考えられる. (2)各削減支保工別にそれぞれ見ても，C II 程度の比 較的良好な地山では, マクロに見てロックボルト, $\mathrm{H}$ 鎆等の支保工の削減による天端沈下量, 内空変位 量への影警は小さい.

(3)ロックボルト削減による他のロックボルト軸力へ の影響は見られない，H鎆削減のケースでは，吹付 けコンクリート応カへの影響, 負担の増加は傾向と して見られた.

(4)支保工の役割は，土圧に対抗する役割よりも，地 山の緩みにより作用する力に抵抗すること，つまり 初期の段階で紱み領域や岩塊の抜け落ちを抑えるこ とにあると考えられ，切羽の評価と支保工の削減の 
基淮もこれらを評価する必要がある.

\section{4. あとがき}

高速道路トンネルの大部分を占める比較的良好な 地山において過去のデータを分析することで，支保 工の変化による変位量への影響は大きくないと考え ることが妥当であると予想されたので, 試験施工を 積み重ねることによってこれを実証することとした. その結果予想どおり支保工の増減が変位量に与える 影響が大きいとする結果は得られず，地山自体の影 響の方がトンネルの挙動に支配的であると考えるこ とが妥当であることが確認された．また，地山によ っては従来(1996年度までの設計要領)のB～D I ま での標準支保パターンから支保量を削減できること がわかった．また J Hは，1997年にこの試験施工に よる削減された支保工の試験施工結果を根执として, 支保量を削減した支保パターンを加えて設計要領 ${ }^{33)}$ の変更を行った，その中では，今回得られた支保工 の役目を考察し, 切羽評価の着目点を明確に記述し ている.

謝辞：本研究は J Hが「支保工のマルチ化」プロ ジェクトの一環として行った一連の試験施工の結果 の一部を取りまとめたものである．試験施工にご協 力頂いた J Hならびに施工関倸者の方々に心から謝 意を表する.

\section{参孝文献}

1） 日本道路公団：設計要領第正集第9編トンネル，pp. 34,1985 年 9 月.

2）(財)鉄道総合技術研究所：N A TMの設計施工指 針, pp. 1, 44, 59, 1987.

3）矢野俊明, 寺田光太郎：片岩地帯におけるN A T M, トンネルと地下, 第12巻8号, pp. 19-28, 1981 年8月.

4）吉川恵也, 朝倉俊弘, 日吉直, 遠藤真一： N A T $\mathrm{M}$ 計測実績の統計分析，第15回岩盤力学に関する シンポジウム講演論文集, pp. 220-224, 1983.

5）関順一, 中村敏夫, 岡田正之, 三輪俊彦: NAT Mにおける変位予測法の適用性, 第18回岩盤力学 に関するシンポジウム講演論文集, pp. 21-25, 1986.

6）土肥楥，高橋祐治，中岛健一：トンネルの施工管 理その 1)，第18回岩盤力学に関するシンポジウ 么 講演論文集, pp. 26-29, 1986.

7）川本茂，五月女隆，亀甲谷義高：第三紀泥岩地帯 におけるNATMの計測管理, トンネルと地下, 第18巻3号, pp. 7-15，1987年3月.

8）佐々木祐三，龟甲谷義高，厒野龍昭：古生層地山 の地山評価と支保の選定, トンネルと地下, 第19 巻 9 号, pp. 37-46, 1988年9月.

9）㩯井春輔，花田基樹，下村弥，大西三郎：鉄筋支
保工の試験施工, トンネルと地下, 第20巻11号, pp. 17-21，1989年11月.

10）西野治彦, 篠川俊夫, 矢田敬 : トンネル切羽観察に 基つくく地山評価方法の検討, 第21回岩盤力学に関す るシンポジウム講演論文集, pp. 266-270, 1989.

11）三浦克，山橋正文，藤井泰雄：破䂶性地山における 支保工の効果について, 第22回土質工学研究発表会, pp. 1641-1644, 1987.

12）五味道義：統計解析によるトンネル掘削に伴うゅる み深さの予測について, 第18回岩盤力学に関するシ ンポジウム講演論文集, pp. 36-39，1986.

13）中田雅博, 鈴木昌次, 古川浩平, 中川浩二：N A T M蓄積データに基づく施工時の地山挙動に関する研 究, 土木学会論文集, No. 567/VI-35, pp. 127-140, 1997.

14）西野治彦, 篠川俊夫, 矢田敬 : 切羽観察に基づく変 位予測と支保選定, 第7回岩の力学国内シンポジウ 厶, pp. 349-354, 1987.

15）樗木武, 平田登基男, 西頭道彦, 相川明：NA TM の数值解析のための地山分類と地山定数, 土と基嗼， Vol. 34, No. 2, pp. 31-37, 1986年2月.

16）日比野敏：岩盤構造物の特徽と岩盤物性評価, 土と 基碟，Vol. 35 , No. 3，pp. 5-7，1987年3月.

17）今津雅紀：岩盤物性のデータバンク化とトンネル の適用，土と基嗼，Vol. 35, No. 3, pp. 9-15, 1987 年3月。

18）磯浦克敏，笹木㭌，関順一，中村敏夫，神藤健一： 強風化花崗岩の風化状態と NATM施工に伴う地山 挙動, 土と基礎, Vol. 28, No.7, pp. 53-59, 1980年 7 月.

19）北川隆：岩盤分類と岩盤一支保相互作用解析，第19 回岩盤力学に関するシンポジウム講演論文集, pp. 281-285, 1987.

20）佐藤正彦, 谷信弘, 集田俊男, 一條俊之：山岳トン ネルの新技術 (27)，トンネルと地下，第20巻6号, pp. 67-73, 1989年6月.

21） 久武勝保：軟岩トンネルでのロックボルト効果に関 する二三の考察, 第8回岩の力学国内シンポジウム 講演論文集, pp. 267-272, 1990.

22）蒋宇静, 江崎哲朗, 横田康行：軟岩トンネル周辺 岩盤の安定機構とその設計について, トンネルエ 学研究論文·報告書第3巻, pp. 17-24, 1993年11月。

23）水谷敏則, 大久保雅憲, 平木博美: 軟岩地山の吹 付けコンクリート覆工の支保機能, 第17回日本道 道路会議論文集, pp. 172-173, 1987.

24）土屋敬：ロックボルトのトンネル補強効果と最適 設計パターンに関する実験的研究, 土木学会論文 集, No. 436/III-16, pp. 17-26, 1991.

25）北條明, 中村真, 打田靖夫, 吉田次男, 管井春輔 : 2 系統の不連続面を有する岩盤におけるロックボル 卜の補强効果, 土木学会第49回年次学術諈演会, III -367 , pp. 724-725, 1994.

26）鹿毛量, 今田徹, 西村和夫：軸力分布からみたロッ クボルトの作用機構, 土木学会第49回学術講演会, III-566, pp. 1122-1123, 1994.

27）今田徹：トンネルの支保構造に関する構造力学的 研究, 1980.

28）岩野政浩, 白川贤志, 真下秀明, 田村沗夫, 宫本 義広：硬岩自由断面掘削機によるトンネル施工時 の地山举動と支保構造に関する検討, トンネル工 学研究論文·報告書第6巻, pp. 23-30，1996年11月.

29）鈴木昌次, 古川浩平, 并上洋司, 中川浩二：NA TM施工実績に基づく事前設計の評価に関する一 
考察，土木学会論文集，第427号/VI-14，pp. 261$270,1991$.

30）日本道路公団：土木工事共通仕様書第12章トンネル 工, pp. 12の3, 1996.

31）中田雅博, 西村和夫, 中野清人：岩石ごとの地山 挙 動に関する研究, トンネルと地下, vol. 29 Nol, pp. 53-63, 1998.

32）日本道路公団：土木工事施工管理要領，トンネル
編, pp. 19, 1988.

33）日本道路公団：設計要領第 III集第9編トンネル， pp. 79，1985年9月.

\section{EXPERIMENTAL STUDY ON THE ROLE OF SUPPORT IN THE MODERATE ROCK MASS}

\section{Masahiro NAKATA, Koji MITANI and Koji NAKAGAWA}

We studied frequency distributions of horizontal convergences( the variation of length between two points on the sides) measured during construction of expressway turnels. The large part of these are small, less than $20 \mathrm{~mm}$ and few supports are deformed These facts suggest issues that vertical and horizontal convergences depend on the support effect or the properties of rock mass, and raise a question about what index we should use for support selection at site. Then we tried to reduce tunnel support in the moderate rock mass at 28 sites. We examined the difference in convergences and support stress in order to study the probability of reducing tumnel support and the effect of it. Judging from this study, it is observed that convergences depend on the ground conditions and the role of support is not to control these displacements, but to prevent falling of rock blocks and loosening of rock mass. 